\title{
Evaluate to Antifungal Effect of Different Concentration of Organic Manure against the Alternaria Leaf Spot of Cabbage
}

\author{
K. M. Solanke*, Sobita Simon, D. T. Bhere and A. S. Chandar \\ Department of Plant Pathology, Sam Higginbottom University of Agriculture, \\ Technology and Sciences, Prayagraj, U. P, India \\ *Corresponding author
}

\section{A B S T R A C T}

\begin{tabular}{|l|}
\hline Key w o r d s \\
$\begin{array}{l}\text { Alternaria leaf spot } \\
\text { of cabbage, } \\
\text { Organic manure }\end{array}$ \\
\hline Article Info \\
\hline $\begin{array}{l}\text { Accepted: } \\
\text { 15 July 2020 } \\
\text { Available Online: } \\
10 \text { August } 2020\end{array}$ \\
\hline
\end{tabular}

An experimental was conducted to see the effect of organic manure against Alternaria leaf spot of cabbage in the plot size $2 X 2 \mathrm{~m}^{2} /$ eight treatment is farm yard manure $5 \mathrm{t} / \mathrm{ha}$ spent mushroom compost $500 \mathrm{~kg} / \mathrm{ha}$, poultry manure $5 \mathrm{t} / \mathrm{ha}$, vermicompost $10 \mathrm{t} / \mathrm{ha}$, neem cake $500 \mathrm{~kg} / \mathrm{ha}$, and leaf mold $3 \mathrm{t} / \mathrm{ha}$, goat manure $10 \mathrm{t} / \mathrm{ha}$, along with the control . Observation each treatment was replicated three times data generally by using RBD design on percentage of disease intensity @ 30,45 and 60 DAT. Observed size of cabbage and head Weight of cabbage and yield. Results that all the organic amendments significantly reduced the incidence of Alternaria leaf spot of cabbage with control whereas among the treatment T2 (Neem Cake) and T1 (Spent Mushroom Compost) significantly reduced incidence of Alternaria leaf spot cabbage as compared with other treatments. Application of farm yard manure @ $5 \mathrm{t} /$ ha increased the yield cabbage. The increased cost benefit ratio was recorded by farm yard manure 5 t/ha. However, among the organic manure amendments of neem cake in the soil @ $500 \mathrm{~kg} / \mathrm{ha}$ was recorded maximum yield with superior quality as compared to other treatments.

\section{Introduction}

Cabbage (Brassica oleracea var capitata L.) is one of the most important vegetables grown worldwide and second most important cole crop after cauliflower. The cabbage consists of thick leaves overlapping tightly on growing main bud called 'head'. Cabbage is very convenient to grow both on large and smallscale (kitchen garden) cultivation (Maritess et al., 2005)

The major cabbage growing countries in world are china, India, Russian Federation,
Japan, Republic of Korea, Ukraine, Indonesia, Poland, Romania and United States of America are the major producing countries in the world with aggregate production of 57, 966, 986 tones (FAO official estimate). The area, production and productivity of cabbage in India were 379.0 ha, 8597.0MT and 22.7MT/ha respectively (National Horticulture Board, www.nhb. gov.in (201415)

The cabbage crop is affected by various fungal as well as bacterial diseases like damping off, club root, downy mildew, 
sclerotinia rot, black leg, black rot, soft rot and Alternaria blight or Alternaria leaf spot. The disease Alternaria leaf spot of cabbage is prevalent in all the cabbage growing states and is one of the major biotic problems, which limits its production and also quality of produce. There are two species of Alternaria which cause serious damage in cabbage: Alternaria brassicae and Alternaria brassicicola, they can survive saprophytically outside of the host and diseased crop debris (Yadav et al., 2014).

The word organic, applied to fertilizers, indicates that the nutrients are derived from the remains or by- products of a once- living organism. Farmers are continually searching for alternatives to synthetic inorganic fertilizers to alleviate the escalating production costs associated with the increasing costs of energy and fertilizers and the problems of soil and surface water deterioration associated with intensive use and release of inorganic fertilizers such as $\mathrm{N}$ and $\mathrm{P}$ fertilizers. Generally, the application of organic amendments to agricultural soils makes good use of natural resources and reduces the need of synthetic inorganic fertilizers. Soil structure, nutrient composition, and microbiological activity of soil are usually increased following the application of organic amendments. (Antonious, 2015)

Organic amendments and chemical fertilizers are especially useful when the soil has poor fertility and productivity (Browning 1983). In addition to soil fertility, soil amendment with inorganic and/or organic matter may also alter soil physical and chemical properties and thereby affect soil microflora (Huang 1991, Huang and Huang 1993).

Sajib et al., (2015) notice that a good agriculture soil should contain at least 5\% organic matter cowdung compost, vermicompost and Trichoderma compost play a viral role to make soil fertile. Cowdung is rich source of different nutrients. It provides $0.5 \% \mathrm{~N}, 0.15 \% \mathrm{P}, 0.5 \% \mathrm{~K}$ and moisture $60+6 \%$.

\section{Materials and Methods}

\section{Field preparation}

The selected field area was well prepared and plot marked as per the layout plan. The selected field was well ploughed, weeded, cleaned and the soil will be pulverized after which the total area is divided into sub-plots.

\section{Cultivation of cabbage}

A F1 hybrid variety BC-76 is chosen for the experiment. All the packages of practices is followed as per the general agronomic practices.

\section{Raising of seedlings}

Nursery bad size of $2.5 \times 1.5 \mathrm{ft}$ was prepared in Department of Plant Pathology for raising seedlings of cabbage. The seed @ 500 gm /ha was sown in the nursery bed, covered with thin layer of soil. According to agricultural package and practice sowing was done at 15 $\mathrm{cm}$ row to row and $10 \mathrm{~cm}$ plant to plant distance. Irrigation was given at all critical growth stages. These raise bed were irrigated whenever required with the help of sprayer.

\section{Compost and manure application}

Well decomposed organic manures viz., vermicompost (10 t/ha), spent mushroom waste $(500 \mathrm{~kg} / \mathrm{ha})$, FYM (5 t/ha), neem cake $(500 \mathrm{~kg} / \mathrm{ha})$ and poultry manure $(5 \mathrm{t} / \mathrm{ha})$ were incorporated in the soil 7 days before transplanting of cabbage (Joshi et al., 2014; Madhumita et al., 2014; Yasmin and Ali 2016). 


\section{Transplantation of seedling}

The healthy seedling of about 25 days old were transplanted to the respective organic manure amended plots. The spicing between plant to plant was $45 \mathrm{~cm}$ and row to row 60 $\mathrm{cm}$. Gap filling were done within the periods of 15 days after transplant.

\section{Intercultural operation}

In a nursery beds, frequent weeding was done for keeping the beds weed free in order to get healthy seedlings. In field, weeding and hoeing were done as and when required to keep the plot weed free and to provide soil aeration.

\section{Appearance of disease}

The disease symptoms was noticed on the plant at 20 DAT and per cent disease incidence was observed at 30, 45, 60 DAT from each treatment each treatment was replicated 3 times (Table 1).

Disease intensity- according to Singh et al., (1982) scale given on scale 0-9 scales was used to record disease intensity.

Disease intensity (\%) was calculated by using the following formula:

\footnotetext{
Sum of all disease ratings

Disease intensity $(\%)=\longrightarrow 100$
}

\section{Symptoms of the disease}

Alternaria leaf spot symptoms start as a small, circular, dark spot, as the disease progresses, the circular spots may grow to $1 / 2$ inch $(1 \mathrm{~cm})$ or more in diameter and are usually gray, gray-tan, or near black in colour. Spots develop in a target pattern of concentric rings on the cabbage head. Conidia are abundantly formed in moist atmosphere and are disseminated by wind rains. On infection the pathogen becomes sub-cuticular in leaves. This followed by colonization of epidermal and mesophyll cells. Under tropical conditions, the disease intensity is high with relative humidity between 79-96 during crop season. In general the disease progresses fast when the maximum temperature ranges between around $16^{\circ}$ and $26^{\circ} \mathrm{C}$ minimum between $1.6^{\circ}$ and $9.6^{\circ} \mathrm{C}$ and wind velocity is between $2.5-6 \mathrm{~km} / \mathrm{hrs}$

\section{Results and Discussion}

\section{At 30 DAYS}

The result of the data at 30, days presented in table 2 and depicted in figure 1 shows that at 30 days after transplants all the organic manure plots significantly reduced the disease incidence $\%$ of Alternaria brassicae as compare with control. Among the treatments of organic amendments \% inhibition of Alternaria brassicae was significantly reduced in T2-neem cake (19.43), and T1Spent Mushroom Compost (20.08) as compared with T3-Vermicompost (21.97), T5-FYM (22.51), T7- Poultry Manure (22.64) and T4-Goat Manure (22.73). Among the treatments (T4, T7, T5, T3) and (T7, T5, T3, T6) (T6, T1,) (T1, T2,) were found nonsignificant from one another.

\section{At 45 DAYS}

The results of the data at 45 , days presented in table 2 and depicted in figure 1 shows that at 45 days after transplants all the organic manure plots significantly reduced the disease incidence $\%$ of Alternaria brassicae as compare with control. Among the treatments of organic amendments \% inhibition of Alternaria brassicae was significantly reduced in T2-neem cake (25.42), and T1Spent Mushroom Compost (26.19) and T6 
leaf mold (26.24) as compared with T3Vermicompost (28.56), T5-FYM (30.61), T7Poultry Manure (31.28) and T4-Goat Manure (32.42). Among the treatments (T4, T7, T5) and (T7, T5, T3) and (T6 T1, T2) were found non- significant from one another.

\section{At 60 DAYS}

The results of the data At 60, DAYS presented in table 2 and depicted in figure 1 shows that at 60 days after transplants all the organic manure plots significantly reduced the disease incidence \% of Alternaria brassicae as compare with control.

Among the treatments of organic amendments $\%$ inhibition of Alternaria brassicae was significantly reduced in T4-Goat Manure (28.52), T2-neem cake (28.59), as compared with T1-Spent Mushroom Compost (30.52) T6 Leaf mold (31.52) T3-Vermicompost (33.87),T7- Poultry Manure 36.26), T5-F YM (38.08). Among the treatments (T5, T7,) and (T3, T6) and (T1, T2, T5) were found nonsignificant different from one another.

The concepts of our results in organic farming for management of alternaria brassicae of cabbage are in similar with the findings of Chaudhary et al., (2018) they found Neem cake most effective organic amendment among manure other after that Joshi et al., (2014)) also found spent mushroom compost are effective on redaction Alternaria brassicae. Similar findings have been reported by Ramatzai et al., (2017).

\section{Effect of organic manure on Cabbage yield (tones/ha)}

The data presented yield of cabbage were recorded at 60 days after transplant table 3 and depicted in figure 2 it was observed that all the organic amendment treatments significantly increased the yield of cabbage as compared with control T0-(15.81 tonnes/ha) Among the organic amendment maximum yield was found in T2 Neem Cake (34.09 tonnes/h a), was superior followed by T1Spent Mushroom Compost (27.37 tonnes/ha),T6-leaf mold (2 5.38 tonnes/ha), T5 -FYM (23.30 tonnes/ha), T3Vermicompost (21.31 tonnes/ha), T4- Goat Manure (20.35 tonnes/ha), T7- Poultry Manure (17.91 tonnes/ha). Among the organic amendments (T3, T4) an found nonsignificant from one another remaining organic amendments plots the yield was significantly different from each other (T6, T4, T2, T1, T5, T0).

Fig.1 Percent disease intensity at 30, 45 and 60 Days as affected by treatments 
Table.1 Details of the treatments of field experiment

\begin{tabular}{|c|c|c|c|c|c|}
\hline Sr.no & Treatments & \multicolumn{2}{|c|}{ Application } & Doses & References \\
\hline T0 & Control & Soil & application & - & - \\
\hline & (Untreated check) & & & & \\
\hline T1 & Spent mushroom waste & Soil & application & $500 \mathrm{~kg} / \mathrm{ha}$ & Joshi et al., (2014) \\
\hline T2 & Neem cake & Soil & application & $500 \mathrm{~kg} / \mathrm{ha}$ & Mukesh et al., (2017) \\
\hline T3 & Vermicompost & Soil & application & $10 \mathrm{t} / \mathrm{ha}$ & Madhumita et al., (2014) \\
\hline T4 & Goat manure & Soil & application & $5 \mathrm{t} / \mathrm{ha}$ & Dhivya et al., (2017) \\
\hline T5 & F.Y.M & Soil & application & $5 \mathrm{t} / \mathrm{ha}$ & Zakari et al., (2014) \\
\hline T6 & Leaf mold & Soil & application & $3 \mathrm{t} / \mathrm{ha}$ & David et al., (1992) \\
\hline T7 & Poultry manure & Soil & application & $5 \mathrm{t} / \mathrm{ha}$ & Yasmin and Ali $\mathbf{( 2 0 1 6 )}$ \\
\hline
\end{tabular}

Table.2 Effect of organic manure against \% of Alternaria leaf spot incidence in cabbage

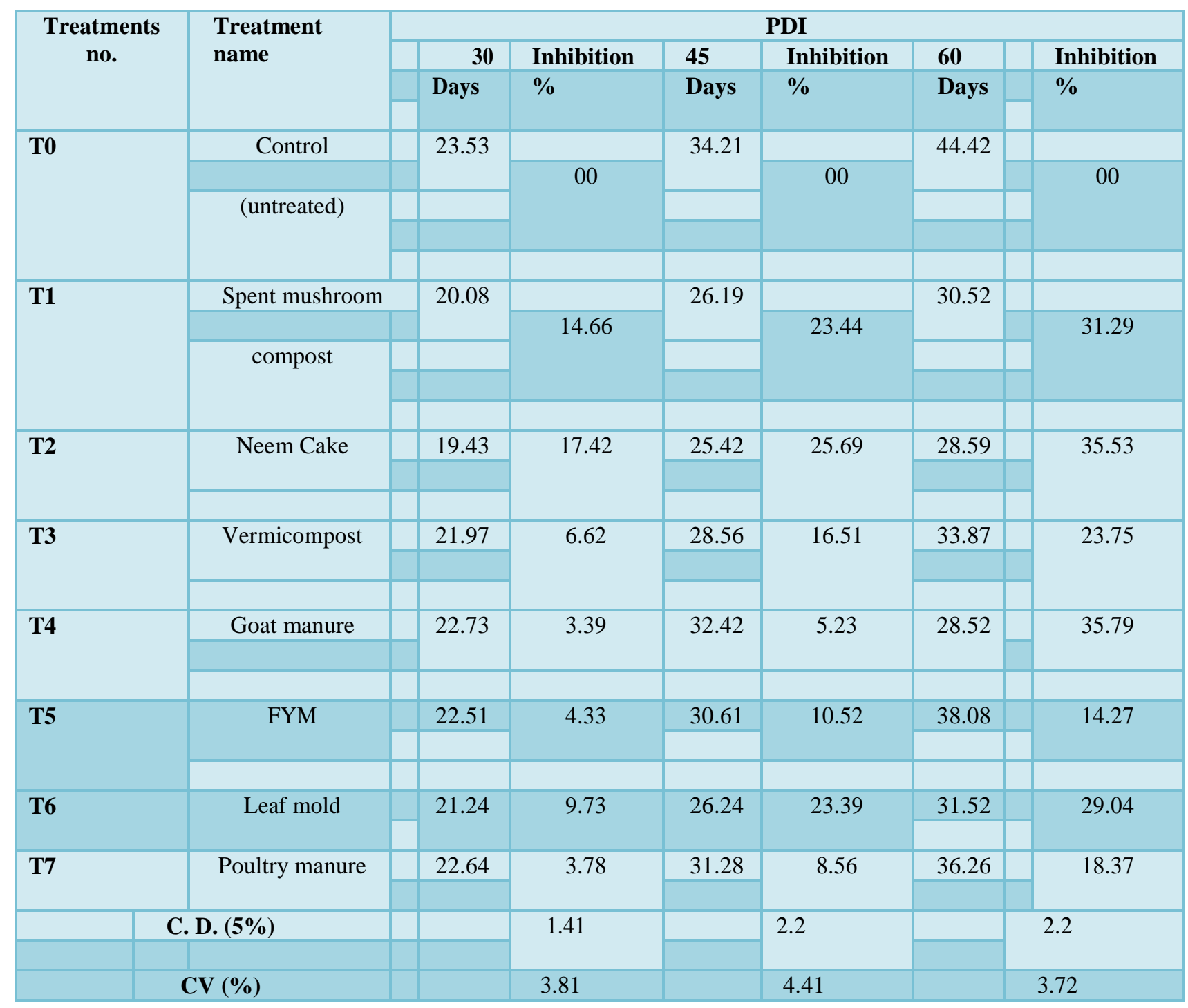


Table.3 Effect of organic manure on Cabbage yield (tones/ha)

\begin{tabular}{|c|c|c|}
\hline Sr No & Treatment & Yield (t/ha) \\
\hline T0 & Control (untreated) & 15.81 \\
\hline T1 & Spent mushroom compost & 27.37 \\
\hline T2 & Neem cake & 34.09 \\
\hline T3 & Vermicompost & 21.31 \\
\hline T4 & Goat manure & 20.35 \\
\hline T5 & FYM & 23.30 \\
\hline T6 & Leaf mold & 25.38 \\
\hline T7 & Poultry manure & 17.91 \\
\hline & SEd \pm C & 0.45 \\
\hline & CD @5\% & 0.9 \\
\hline & CV $(\%)$ & 2.19 \\
\hline
\end{tabular}

Fig.2 Effect of organic manure on Cabbage yield (tones/ha)

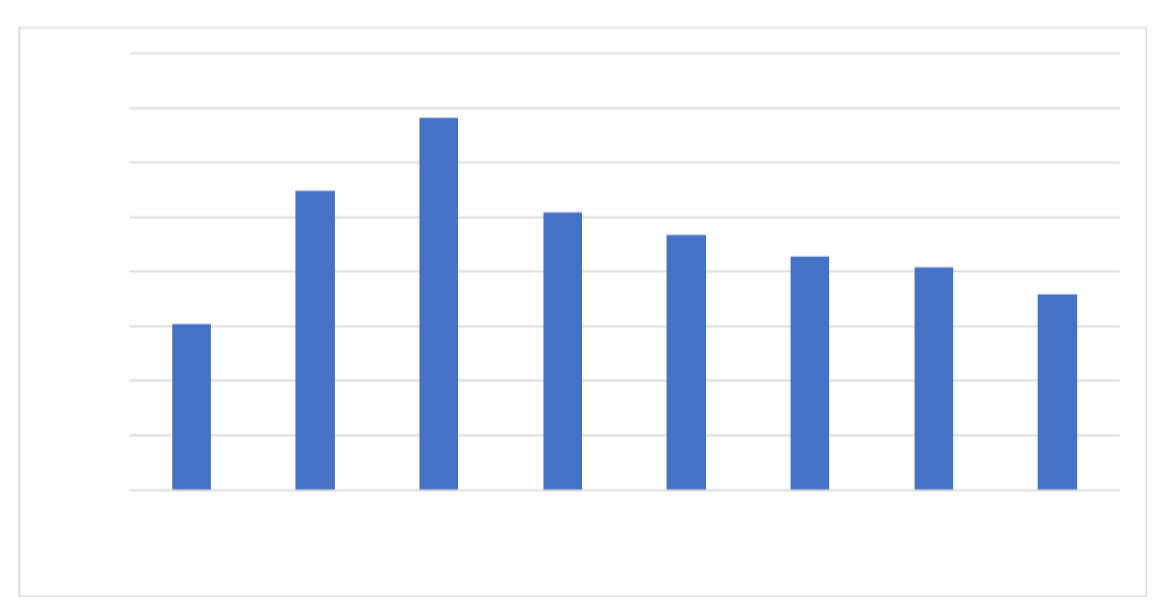

Experiment revealed that organic manure significantly reduced the Alternaria leaf spot of Cabbage (Alternaria brassicae) where among the organic manure amendments soil application farm yard manure @ 6.0 tonns/ha increased the yield. The maximum cost benefit ratio was recorded by Farm yard manure 6.0 tons/ha. Thus, according to experimental finding and results discussed in the earlier chapter, it is concluded that organic manure reduced the Alternaria leaf spot of Cabbage (Alternaria brassicae) where among the organic manure amendments soil application of farm yard manure $27.37 \mathrm{~kg} / \mathrm{ha}$ found maximum yield was significantly superior as compare to other treatments Chaudhary et al., (2018).

In conclusion the present study, It is concluded that Neem cake @ $500 \mathrm{~kg} / \mathrm{ha}$ and Spent mushroom compost $500 \mathrm{~kg} / \mathrm{ha}$ were found most effective in managing the Alternaria leaf spot of Cabbage with better yield.

\section{References}

Adenij I, O.T., Swai, I., Oluoch, M.O., Tanyongana, R. and Aloyce, A. (2010). Evaluation of head yield and 
participatory selection of horticultural characters in cabbage (Brassica oleraceae) Crop Science. 2(8):243-250.

Ali GA (2005). Uses of manure and fertilizer as soil management technique for sustainable crop production. Paper presented at a workshop organized by Taraba State Local Government Service Commission on 8 and 9, December 2005

Antonious, GF. Decontamination of pesticide residues for sustainable agriculture. JSM Environ Sci Ecol 2015, 1/7-7/7.

Browning, J.A. (1983). Whither plant pathology? Whither plant health? Plant Dis. 67: 575-577

Chaudhary, S. K., S. K. Yadav, D. K. Mahto, R. P. Sharma and Mahesh Kumar (2018) Response of Growth, Yield Attributes and Yield of Cabbage (Brassica ole racea var. capitata) to Different Organic and Inorganic Sources of Nutrients in Magadha Plain of Bihar. International Journal of Current Microbiology and Applie Sciences, (7): 4748-4756.

Dauda SN, Aliyu L, Chiezey UF (2005). Effect of variety, seedling age and poultry manure on growth and yield of garden egg (Solanum gilo L.) Nigeria. Nigerian Acad. Forum 9:88-95.

Dhivya, M., Muthamilan, M., Kalaivanan, R., Devrajan, K. and Chinnaiah, C. (2017). Effect of Oilcakes on the management of wilt disease of tomato caused by Fusarium oxysporum f. sp. lycopersici. International Journal of Current Microbiology and Applied Sciences, 6(12): 2138-2140.

Jenn-Wen Huang Department of Plant Pathology National Chung-Hsing University Taichung 402, Taiwan ROC(2009) Management of Crop Diseases With Agricultural Wastes.

Joshi, D., Hooda, K.S., Bhatt, J.C., Mina, B.L. and Gupta, H.S. (2009). Suppressive effect of composts on soil-borne and foliar disease of French bean in the field in western Indian Himalayas. Crop Prot., 28: 608-615

Joshi, R., Singh. J. and Vig, A. P. (2014). Spent mushroom waste as an effective organic fertilizer and biocontrol agent: effect on growth, yield and quality of plants. Review in Environmental Science and Biotechnology, 10(10): 1157-1159.

Madhumita, P., Sobita, S. and Neelam (2014). Effect of organic soil amendment and soil solarization on wilt of chickpea. International Journal of Botany and Research (IJBR), 4(3): 61-66.

Maritess, C, Small S, Waltz-Hill M (2005). Alternative nutrition therapies in cancer patients. Sem Oncol Nurs, 21: 173-6.

Mukesh, K., Jat, R., Ahir, R., Sanju, C. and Kakaraliya, G. (2017). Management of coriander wilt (Fusarium oxysporum) through cultural practices as organic amendments. Journal of Pharmacognoscy and Phytochemistry, 6(5): 31-33.

Okito AB, Alves JR, Urquiaga S, Boddey RM (2004). Isotopic Fractionation during nitrogen manure to other source of organic manure in terms of fixation by four tropical legumes. Soil Biol. Chem. 36:1189-1190

Rahman, SA (2004). The Place of Organic Manure in Sustaining Agricultural Development in Nigeria. Paper presented at Science Technology and Society National Workshop in Lafia, Nasarawa State. Nigeria.

Rahman, M.M. and Ali, M.A. (2016). Effect of organic amendment on stem canker and black scurf disease of potato (Solanum tuberosum). Bioscience Journal Uberlandi. 32(2):361-370.

Tejada,M., Gsomez, I., Hernandez, T. and Garcia, C. (2010). "Utilization of vermicompost in soil restoration: 
effects of soil biological properties", Soil Science Society of America Journal, 74(2): 525-532.

Tiwari, K. N., Singh, P. K. and Mal, P. K. (2003). Effect of drip irrigation on the yield of cabbage (Brassica oleracea $\mathrm{L}$. var. capitata) under mulch and nonmulch conditions. Agric. Water Manag., 58: 19- 28.

Yasmin, L. and Ali, M. (2016). Use of organic amendment for management of
Fusarium wilt of gladiolus. Bangladesh Journal of Agrilcultural Research, 41(4): 675-684.

Zakari, S. M., Miko, S. and Aliyu, B. S. (2014). Effect of different types and levels of organic manures on yield and yield components of garlic (Allium sativum L.) at Kadawa, Kano, Nigeria. Bayero. Journal of Pure and Applied Sciences, 7(1):121-126.

\section{How to cite this article:}

Solanke, K. M., Sobita Simon, D. T. Bhere and Chandar, A. S. 2020. Evaluate to Antifungal Effect of Different Concentration of Organic Manure against the Alternaria Leaf Spot of Cabbage. Int.J.Curr.Microbiol.App.Sci. 9(08): 1182-1189.

doi: https://doi.org/10.20546/ijcmas.2020.908.131 